\title{
Social Media Tools in the Leadership Classroom: Students' Perceptions of Use
}

\author{
Summer F. Odom \\ Assistant Professor \\ Department of Agricultural Leadership, Education, \& Communications \\ 2116 TAMU \\ Texas A\&M University \\ College Station, TX 77843-2116 \\ summerodom@tamu.edu \\ Holly D. Jarvis \\ Department of Agricultural Leadership, Education, \& Communications \\ 2116 TAMU \\ Texas A\&M University \\ College Station, TX 77843-2116 \\ hollydjarvis@live.com \\ M'Randa R. Sandlin \\ Department of Agricultural Leadership, Education, \& Communications \\ 2116 TAMU \\ Texas A\&M University \\ College Station, TX 77843-2116 \\ mranda.sandlin@agnet.tamu.edu \\ Cassidy Peek \\ Department of Agricultural Leadership, Education, \& Communications \\ 2116 TAMU \\ Texas A\&M University \\ College Station, TX 77843-2116 \\ cassidy.peek@agnet.tamu.edu
}

\begin{abstract}
Social media is becoming more prevalent in the higher education classroom. As part of an ongoing study, the Department of Agricultural Leadership, Education, and Communications at Texas A\&M University surveyed leadership students about their perceptions of their level of comfort and frequency of use of social media tools and the advantages and disadvantages that these students perceived when social media was used in the leadership classroom. A total of 79 students were surveyed in two upper level leadership courses. Facebook was the social media tool students were most comfortable with and used most frequently.
\end{abstract}


Advantages included social media helping increase quality and efficiency of communication between students and the instructor, social media as a technological norm, access to class information, ease of collaboration, and stronger social connections between classmates. Disadvantages revolved around issues of use of and access to social media.

\section{Introduction}

As technology and social media use by students becomes more prevalent, educators, especially in higher education, are seeking ways to use such tools to remain relevant and appropriate to their audience. Little research exists that indicates how to harness the students' use of social media tools in the leadership classroom and what impacts it could have on leadership education and the its application. Fidishun (2000) found "it is possible to create lessons that not only serve the needs of students to use the latest technology but also focus on their requirements as an adult" (p. 76). As adults college students are increasingly required to be self-directed with their time, attention, and effort. Learning models that are andragogical or those that focus on adult learning as opposed to the learning of younger students contend that adults develop their own means of attaining knowledge and that they are intrinsically motivated to learn. One way that informal learning occurs now is through public pedagogy, or the learning that takes place informally through social media (Freishtat \& Sandlin, 2010). Social media uses are widely varied in higher education classrooms and include blogging (Gifford, 2010), the use of wikis (Laru, Naykki, \& Jarvela, 2012), social annotation (Novak, Razzouk, \& Johnson, 2012), and the use of Facebook and Twitter (Settle, Telg, Irani, Rhoades, \& Rutherford, 2011). Researchers have found that a carefully planned application of a social media tool can have a great influence on student learning and engagement with material (Gifford, 2010; Laru et al., 2012; Novak et al., 2012); these findings could have implications for the processing and application of learned material in the leadership classroom.

\section{Literature Review}

\section{Pedagogical to Andragogical Learning}

A myriad of teaching approaches have been identified, studied, confirmed, and refuted. The two overarching theories that address teaching approaches are pedagogy and andragogy. A pedagogical approach to education is generally teacher-centered; learners have minimal to no role in the eight-step process model of education (Knowles, Holton, \& Swanson, 2005). On the other hand, andragogy is a mutual educational process that is facilitated by the educator. Learners are active participants in all aspects of their education, from the planning to the evaluation (Knowles et al., 2005). Fidishun (2000) found that "to facilitate the use of andragogy while teaching with technology we must use technology to its fullest" (p. 78). 
Educators who understand the needs of adult learners and the core learning principles of andragogy will be better able to engage adult audiences. According to Knowles et al. (2005), there are six core adult learning principles - learner's need to know, self-concept of the learner, the learner's prior experience, readiness to learn, orientation to learning, and motivation to learn. Adult learners must be involved in the education process; they must be active seekers, participants, and evaluators.

Higher education pushes students to become increasingly self-directed. The Staged Self-Directed Learning Model indicates that learners move from dependent, interested, and involved, to self-directed learners (Grow, 1991). Educators in this process begin as an authority figure and, in the end, are merely consultants or delegators. Few undergraduate students can be expected to efficiently function at the stage four, self-directed learner capacity, due to the nature of higher education and mass information delivery. In stage three, however, the involved learner is educated by a facilitator. It is in this stage that social media can be used for the facilitation of discussion and group projects. At earlier stages, social media can be used by instructors to point students to certain parts of a text, asks pointed questions about models or articles found online, or to illustrate ways that instructors process and think about the material students are studying (Brown, 2012). All of these strategies promote independent engagement with course content.

As noted by Bloom's Taxonomy (cited in Marzano \& Kendall, 2008), selfdirected learners must also be cognitively, affectively, and physically stimulated to process information. Cognitive learning involves information retention, comprehension, application, and analysis. Affective learning includes learner attitudes and the manner in which the learner values and emotionally processes information. Physical, or psychomotor learning, is learning through movement and motor-skill use. The use of social media engages all three of these domains. Through the posting of information, learners are able to cognitively apprehend material and affectively process the information. Students are also able to share their cognitive and affective responses through discussions and conversation threads. Students may seek articles, websites, videos, or even create videos to share via social media tools. This active engagement with the learned information extends students' learning into the psychomotor domain.

Learners who feel a sense of ownership in their education are more motivated to learn (Platz, 1994). Platz advocates the use of the Student Directed Learning model. This model is presented as a supplementary educational tool for use with younger students. In assessing the needs and desires of adult learners, as presented by Knowles et al. (2005), the Student Directed Learning model also meets the educational needs of adult learners, as well as students who are developing selfdirected learning skills. This model is implemented in four stages: examples, student selected-teacher activities, student selected-student activities, and student directed planning. By developing student confidence and subject matter 
competence and establishing teacher expectations in the first three stages, learners are prepared to develop their own learning activities in stage four (Platz, 1994).

\section{Uses of Social Media in the Higher Education Classroom}

The use of social media in the classroom is a method that combines andragogical teaching methods and increasingly self-directed learning. Williams and McClure (2010) found that "faculty must be open to modifying their teaching methods" (p. 94). They also found that information delivered via public pedagogy or popular media as an educational tool, increased knowledge retention. Guthrie (2009) found that by embedding learning in a technology framework, students "were able to learn beyond the learning outcomes" (p. 135).

Social media tools are changing the way students learn and how teachers teach in higher education. Brown (2012) found that university instructors could be classified into three categories when it came to perceptions of the potential of social media to make an impact on class activities. Some instructors perceived that it was not useful at all, which agrees with Settle, Telg, Irani, Rhoades, and Rutherford (2011) who found that instructors did not want to deliver course content through social media. Other groups in Brown's (2012) study were open to content delivered by either tutors or by instructors. A German study showed that as much as one-fifth of student-populated social media groups have some sort of knowledge exchange function, but that students who were further along in their studies were less likely to participate in these types of groups (Wodzicki, Schwammlien, \& Moskaliuk, 2012). Wodzicki et al. concluded that social media was better suited for informal learning than for formal learning. A Chinese study suggested that there was a definite link between the use of social media and gains in cognitive, affective, and psychomotor learning domains (Yan, Tian, Vogel, \& Kwok, 2010). Considering leadership students specifically, Wisniewski (2010) found that they are resistant to traditional pedagogical techniques and they seemed to prefer digital paradigms.

Uses of social media in university settings vary widely. One group of professors developed software which would allow them to integrate social media with large section lectures to make them more interactive. Their students were able to chat with each other about class content, submit questions to the professor during the lecture, and vote on which questions should be answered first (Chao, Parker, \& Fontana, 2011). Dabbagh and Kitsantas (2012) recommend that personalized learning environments which can be adjusted to each individual student's needs should be implemented to emphasize student-centered learning design. One means of promoting interaction between students through the use of social media is through a tool known as social annotation (Novak et al., 2012). This tool is used so that groups of students can collaborate on projects, critique writing, and discuss readings. 
Blogging is another social media tool used in higher education. Gifford (2010) used blogs in a leadership class to promote higher level thinking and found that students who blogged earned more points in class than those who did not. Blogging can be used to promote self-reflection which is important to leadership development (Roberts \& Dyer, 2008). Laru et al. (2012) found that the number of blog posts by students was the most influential factor on student success in the class, though this class focused more on the use and development of wikis than on the production of a blog. However, Top (2012) found that students participating in blogging perceived that blogging did not have any great effect on their learning. Top (2012) also suggests that building community among students in an online environment should be a priority for an instructor. Other researchers suggest that people need to be aware of the levels of intimacy associated with the influx of social media into the modern world and work to promote a new understanding of intimacy as being genuinely present with others, either through social media or face-to-face (Van Manen, 2010).

Use of social media can help or hinder the achievement of student learning outcomes. The type of social media tool used varies by the desired outcome. Settle et al. (2011) found that $28.4 \%$ of instructors used Facebook and only $7.8 \%$ used microblogs such as Twitter for communicating with students. Instructors in that study noted that these two formats were the least desirable modes of transmitting content to students. It has been noted that some social media tools are well-suited for promoting learning and others are not (Brown, 2012). Brown wrote that social media should be used to promote student-centered learning. Content-driven exercises found on many e-learning sites may not promote students taking responsibility for their own learning (Dabbagh \& Kitsantas, 2012). Lack of student knowledge of computer technology can hinder the achievement of student learning outcomes when social media is used. Several studies have found that students, and in particular agriculture students, are not as savvy with technology as expected (Skurat-Harris, 2010; Johnson, Ferguson, \& Lester, 2000; Johnson, Ferguson, \& Lester, 2004, Johnson \& Warlow, 2004). Thomas, Davis, and Moss (2008) explain a process used in agricultural extension in which instructors were trained in the use of blended online environments and described the program as a success for those instructors. While Thomas et al. aimed his work at training instructors, Novak, Razzouk, and Johnson (2012) balance that concern by focusing on training for students in the particular social media tool to be used in the class. This approach could bring increased success for students because Top (2012) found that computer knowledge was the strongest predictor of student learning in a course using social media.

While the applications of social media vary, and there are still those who are resistant to incorporating these tools into university coursework, many different kinds of benefits have been found for students using social media in their classes. With a push for efficiency in higher education (Franklin \& Van Harmelen, 2007) and an increase in constructivist paradigms being applied in university settings (Wisniewski, 2010), using social media in a carefully designed setting (Laru et al., 
2012) with support and training for both instructors (Thomas et al, 2008) and students (Novak et al., 2012) can make social media a way for students to learn to connect among themselves (Top, 2012) and connect on a deeper level with course content (Laru et al., 2012).

\section{Need for Study}

Social media tools have been identified as an effective educational platform (Laru et al., 2012; Top, 2012) and social media tools are already being used in the leadership classroom at Texas A\&M University and elsewhere. Several leadership theories and approaches such as transformational leadership, situational leadership, and leader-member exchange (LMX) focus on the notion of relating to and connecting with followers. Leadership is a relational process and involves connections with individuals (Bass, 2008). There is a need to better understand the perspective of students and how to connect with them through the use of social media tools in the leadership classroom. This study sought to identify for leadership educators the potential impacts, implications, and recommendations for the use of social media in leadership courses based on the perceptions and needs of leadership students themselves.

\section{Theoretical Framework}

The theoretical framework for this study is based on Tu and McIsaac's (2002) expanded findings of the variables contributing to social presence theory (see Table 1). Social presence theory was originally developed within the social science fields as a means of explaining the degree of salience, meaning the state or quality of being present that exists between two communicators using a specified communication medium (Short, Williams, \& Christie, 1976). Short et al. proposed that communication mediums differ in their degree of social presence which affects how people interact. People perceive some communication media as having a higher degree of social presence than others. Many researchers have studied social presence theory and ways to measure this phenomenon (Gunawardena, 1995; Gunawardena \& Zittle, 1997; Garrison, Anderson, \& Archer, 2000; Rourke, Anderson, Garrison, \& Archer, 2001; Swan, 2003; Hughes, Ventura, \& Dando, 2007). Tu and McIsaac (2002) developed an instrument that measures social presence via four constructs - social context, online communication, interactivity, and privacy. Social context refers to social processes, settings and purposes that affect social presence such as social relationships, task complexity, task interdependence, and environmental uncertainty. Online communication involves the user's expertise in language used and application of it in online experiences. Interactivity includes those activities through which the communicator and communication medium interact and how often feedback occurs. The privacy construct is the degree to which the communicator and communication medium allows for privacy. While the Tu and McIsaac measure of social presence took into account many variables of social presence, they also concluded social presence was more complicated and 
warranted further study. Table 1 illustrates the variables that they determined contributed to social presence.

Table 1

Variables Contributing to Social Presence Theory Dimensions

\begin{tabular}{|c|c|c|c|c|}
\hline \multicolumn{5}{|c|}{ Dimensions } \\
\hline Variables & I. Social Context & II. Online Communication & III. Interactivity & IV. Privacy \\
\hline 1 & $\begin{array}{l}\text { Familiarity with } \\
\text { recipients }\end{array}$ & $\begin{array}{l}\text { Keyboarding and } \\
\text { accuracy skills }\end{array}$ & Timely response & $\begin{array}{l}\text { Formats of } \\
\text { CMC }\end{array}$ \\
\hline 2 & $\begin{array}{l}\text { Assertive/ } \\
\text { acquiescent }\end{array}$ & $\begin{array}{l}\text { Use of emoticons and } \\
\text { paralanguage }\end{array}$ & $\begin{array}{l}\text { Communication } \\
\text { styles }\end{array}$ & $\begin{array}{l}\text { Access and } \\
\text { location }\end{array}$ \\
\hline 3 & $\begin{array}{l}\text { Informal/formal } \\
\text { relationship }\end{array}$ & $\begin{array}{l}\text { Characteristics of real- } \\
\text { time discussion }\end{array}$ & $\begin{array}{l}\text { Length of } \\
\text { messages }\end{array}$ & $\begin{array}{l}\text { Patterns of } \\
\text { CMC }\end{array}$ \\
\hline 4 & Trust relationships & $\begin{array}{l}\text { Characteristics of } \\
\text { discussion boards }\end{array}$ & Formal/ informal & \\
\hline 5 & Social relationships & Language skills & Type of tasks & \\
\hline 6 & $\begin{array}{l}\text { Psychological } \\
\text { attitude toward } \\
\text { technology }\end{array}$ & & Size of groups & \\
\hline 7 & Access and location & & $\begin{array}{l}\text { Communication } \\
\text { strategies }\end{array}$ & \\
\hline 8 & $\begin{array}{l}\text { User's } \\
\text { characteristics }\end{array}$ & & & \\
\hline
\end{tabular}

Note. $\mathrm{CMC}=$ computer-mediated communication. Adapted from "The Relationship of Social Presence and Interaction in Online Classes," by C. H. Tu and M. McIsaac, 2002, American Journal of Distance Education, 16(3), p. 141. Copyright 2002 by the American Journal of Distance Education.

Tu and McIsaac's (2002) variables contributing to social presence dimensions serve as a framework for examining the degree of presence among teachers and students when utilizing social media tools in a leadership course. Additionally, through the application of a carefully designed plan to incorporate social media into the higher education classroom, instructors can effectively engage students at lower levels of Grow's (1991) model, raising their level of engagement with course content. This effectively helps students transition away from a pedagogical model toward an andragogical model (Knowles et al., 2005), helps students engage course content on a deep level (Laru et al., 2012), and provides students with a means of connecting in a meaningful way with each other and the instructor through social media (Tu \& McIsaac, 2002). University level students are engaging in social media regularly for informal learning (Wodzicki et al., 2012), but their perceptions of social media use in the leadership classroom have yet to be explored. Brown (2012) noted that leadership students seemed to prefer 
digital learning approaches, but student engagement in a mixed teaching design when formal learning strategies, social media, and digitally formatted learning experiences are incorporated, need to be studied to satisfy both the educator and the learner.

\section{Purpose and Objectives}

This study explored student perceptions of the use of social media in a leadership course, their current use of social media, and their comfort level with specific social media tools. Specific objectives of the study included:

- Describe participants in terms of their comfort level with specific social media tools.

- Describe participants in terms of their current use of specific social media tools.

- Describe the perceptions of students enrolled in selected leadership courses about the use of social media in the classroom.

\section{Methods}

This study uses a parallel mixed method approach which incorporates both qualitative and quantitative strands, as outlined by Morse (2003). Parallel mixed designs are designs where "mixing occurs in a parallel manner, either simultaneously or with some time lapse; planned and implemented [qualitative] and [quantitative] phases answer related aspects of the same questions" (Teddlie \& Tashakkori, 2009, p. 151).

\section{Population and Sample}

The population frame for this study was undergraduate students enrolled in two leadership courses at Texas A\&M University with a total population frame of 92 students. A census was attempted in both courses and the instrument was administered to each student present on the class day it was given. The final sample consisted of 79 responses. The first course was a personal leadership development course ( $n=49$ students), and the second course was an upper level leadership elective course ( $n=30$ students).

\section{Instrumentation}

The instrument for this study consisted of two parts. The quantitative section addressed student perceptions regarding comfort level with and current use of social media tools (Facebook, Twitter, blogging, and Wiggio). In the qualitative section, students were asked to describe their perceived advantages and disadvantages of the use of social media in the classroom. A team of leadership 
scholars at Texas A\&M University analyzed the content and face validity of the instrument.

Additional descriptive data was also collected. Students were asked to indicate gender, race, grade expectation, and current GPA. The instrument also included questions about student employment and cell phone ownership. Additional items asked about frequency and mode of Internet access.

\section{Data Collection and Analysis}

In an effort to sample the entire population frame undergraduates in two leadership courses were given time to complete the instrument during class. The instrument was administered during class and no identifying information was collected from the student to connect them to their responses. Two separate processes were involved in the parallel mixed method study analysis (Teddlie \& Tashakkori, 2009) - qualitative data were analyzed using thematic analysis and quantitative data were analyzed using descriptive statistics. Each method will be presented separately.

The qualitative data was analyzed using content analysis, a "technique that enables researchers to study human behavior in an indirect way, through an analysis of their communications" (Ary, Jacobs, \& Sorensen, 2010, p. 457). Specifically, this study used an open coding technique (Strauss, 1987). The open coding technique, the constant comparative method, includes four stages (a) comparing units applicable to each category, (b) integrating all categories and their properties, (c) delimiting the theory, and (d) writing the theory (Glaser \& Strauss, 1967). Each participant was assigned a unique numerical identifier, and then participants' responses were analyzed and grouped into themes. Participants were asked to list advantages of using social media in a class and then to list disadvantages. Responses were assigned a numerical and letter identifier. An example of the coding - 3A, the number represents the participant; the letter represents if the response was an advantage (A) or disadvantage (D). Participant responses were analyzed to determine themes using words, phrases, and sentences as the units of analysis.

Quantitative data consisted of responses from participants on questions related to the comfort level and frequency of use of the following social media tools:

Facebook, Twitter, blogging, and Wiggio. Participants were asked to rate their comfort level and frequency of use of the social media tool using a five-point summated scale. Quantitative data were entered into SPSS version 17.0 for analysis and the data were examined using descriptive statistics. Descriptive statistics allow researchers to describe and give general information about a specific group using the gathered data (Black, 2001). An analysis of the data included means and standard deviations for each social media tool. 


\section{Findings}

The first objective of the study was to describe students' perceived comfort level with certain types of social media tools. Students were most comfortable with Facebook $(M=4.35, S D=.96)$. Students were less comfortable using Twitter $(M=2.85, S D=1.31)$. Wiggio $(M=2.49, S D=1.05)$ and Blogging $(M=2.37$, $S D=1.07)$ were the types of social media with which students were least comfortable (see Table 2). Due to the relatively large standard deviations, mode and range of scores was also reported because of the potential for the mean to be misleading.

Table 2

Descriptive Statistics for Students' Perceived Comfort Level with Social Media

\begin{tabular}{lcccccc}
\hline Social Media Tool & $N$ & $M$ & $S D$ & Mode & Min & Max \\
\hline Facebook & 79 & 4.35 & 0.96 & 5 & 1 & 5 \\
Twitter & 79 & 2.85 & 1.31 & 3 & 1 & 5 \\
Wiggio & 79 & 2.49 & 1.05 & 3 & 1 & 5 \\
Blogging & 79 & 2.37 & 1.07 & 3 & 1 & 5 \\
\hline
\end{tabular}

Note. Scale: $5=$ very comfortable, $4=$ comfortable, $3=$ neither uncomfortable nor comfortable, 2 $=$ uncomfortable, $1=$ very uncomfortable.

The second objective of the study was to describe participants in terms of their current frequency of use of a specific type of social media. Students reported that Facebook was the type of social media used most frequently $(M=3.91, S D=.93)$. Twitter $(M=2.11, S D=1.41)$ was used less frequently by students. Blogging $(M=1.39, S D=.63)$ and Wiggio $(M=1.37, S D=.64)$ were the types of social media reported by students as used least frequently (see Table 3). Due to the relatively large standard deviations, mode and range of scores was also reported because of the potential for the mean to be misleading.

Table 3

Descriptive Statistics for student's Perceived Frequency of Use of Social Media

\begin{tabular}{lcccccc}
\hline Social Media Tool & $N$ & $M$ & $S D$ & Mode & Min & Max \\
\hline Facebook & 79 & 3.91 & 0.93 & 4 & 1 & 5 \\
Twitter & 79 & 2.11 & 1.41 & 1 & 1 & 5 \\
Blogging & 79 & 1.39 & 0.63 & 1 & 1 & 3 \\
Wiggio & 79 & 1.37 & 0.64 & 1 & 1 & 3 \\
\hline
\end{tabular}

Note. Scale: 5 = as often as I can throughout the day, $4=$ daily, $3=$ once or twice a week, $2=$ less than once or twice a week, 1 = have never used. 
The last objective of the study sought to describe the perceptions of students enrolled in selected leadership courses about the use of social media in the classroom. Students were asked to list advantages and disadvantages of the use of social media in the classroom. As the qualitative results of this study were analyzed, six key themes emerged in regards to the advantages and five key themes emerged from disadvantages associated with the implementation of social media into leadership education courses.

\section{Advantages}

Responses provided by the students showed they were open to the idea of using social media outlets as a tool in leadership classes and saw them as a benefit. Six themes emerged as the responses were analyzed. The first advantage the students reported was the expected increase in quality and efficiency of communication that would occur as a result of the use of social media in their leadership courses. Furthermore, they mentioned an increase in the rate at which information could be shared or provided. One respondent noted social media would allow for "faster streaming of information to the students" (60A), and another indicated it is "a practically instantaneous way to receive info" (53A). Many respondents indicated they believed social media would allow them to do a better job of staying in contact with others, including with other students in the class and even the professor. One student wrote this "allows for painless communications" (61A) and another mentioned that it "makes interaction between students and teachers much easier" (40A).

The second theme within advantages was social media as a technological norm. Many participants cited this as their reason for believing social media tools could be beneficial. A majority of the students in this study were already active on Facebook, Twitter, or another social media website. Social media use in the classroom makes it possible to "relay messages quickly in a realm that people use constantly" (50A). One student thought this could possibly improve student performance in the course because "students are more likely to check assignments/class page when on a social media site due to the fact that they check their accounts multiple times a day" (66A). It would also provide an enjoyable outlet for students to use as a networking tool within the class. These websites "add a little 'fun' by incorporating one of today's biggest and most popular social media contributions" (19A).

Dissemination of information in regards to class context and management was another prominent theme which emerged as an advantage. The responses showed many of the individuals believed social media would help them stay connected to what was going on in the course and also help keep them in touch with members from their group project teams. One respondent indicated that this would allow students to easily "keep up with due dates on assignments or missed assignments through other classmates" (38A). 
Ease of collaboration that is a direct result of social media also emerged as a theme. The use of these tools means "group scheduling is easier" (5A), and groups "can communicate at any time" (45A). In addition to effective communication and team collaboration, social media can allow students to engage a "peer group to help solve problems" (32A).

Respondents indicated a belief that social media tools are a way to network and form stronger connections with their classmates. Social media allows individuals to "get to know people on a deeper level" (35A) and is an effective way to "bring the class together" (63A).

Students viewed social media as being an effective learning tool. Respondents noted that social media "can make class time more impactful" (8A), "motivate students to keep up or be more engaged in the course work" (70A), and "appeal to students with different learning styles" (70A). Most of the responses reflected the idea that using social media in a leadership education course would improve communication, collaboration, and networking.

\section{Disadvantages}

While advantages do exist, there are also disadvantages that should be taken into consideration. The students described potential downfalls that could result from the use of social media in leadership education. Five key themes emerged.

Many students responded that social media use in a classroom setting could be a distraction as a learning resource. If students were to misuse social media tools, it would "make for more of a distraction than a tool" (21D). Respondents expressed a preference for maintaining separation between education and their social lives. By integrating the educational and social functions of social media, participants would not have "separation from personal life" (19D).

While it may appear that the vast majority of college-aged students use social media regularly, there are still individuals who do not. One respondent suggested that instructors "make [social media use] optional" (37D). Respondents were concerned with keeping up with multiple social media sources. One student stated, "I would hate to have missed important info if I were not able to always check all of the outlets" (40D).

Several respondents chose not to use social media because they are not comfortable with the technology. A respondent stated, "Students or instructors who are unfamiliar with social media sites could be placed at a disadvantage" (3D). Respondents were concerned that non-use of social media could lead them to have a less successful experience in the classroom. While it may appear that most students are comfortable with social media, "people who are not comfortable are less likely to use the tools" (29D). 
Loss of classroom interface is another disadvantage that emerged from the students' responses. Some believe that using social media tools "seems to defeat the purpose of sitting in a classroom" (6D). Respondents reflected that the use of social media could "make it feel more like an online class" (11D) and "take away from a 'professional' setting" (20D).

Respondents also noted problems with Internet access and consistency in the specific type of social media tool used in the course. One participant said, "Everyone takes the Internet for granted and those of us that are without it then have to do more to contribute" (12D). Another respondent commented, "Not everyone uses the same type of social media" (8D). Most students indicated that social media disadvantages include misuse, non-participation, possible unfamiliarity with the specific tool, and the loss of classroom interface.

\section{Conclusions}

The notion of relating to and connecting with followers is central to several theories and approaches to leadership such as transformational leadership, situational leadership, and leader member exchange (Bass, 2008). As leadership educators attempt to model the way for their students, they can model the behavior of attempting to connect with and relate to students through the use of social media. Because social media has become so integral to the lives of students, it seems imperative that leadership educators seek to understand how they can integrate social media into their courses in order to be relevant and relate to their students.

Students in two upper-level leadership courses were asked to provide feedback about social media use in the leadership classroom. The collected data were both quantitative and qualitative. The quantitative data were used to describe the students in terms of their perceived comfort level with social media and frequency of use of social media tools. The qualitative data explored the perceived advantages and disadvantages of social media use in the leadership classroom.

In assessing the students comfort level with social media tools, students reported a higher comfort level with Facebook than with Twitter, Wiggio, or blogging. A majority of students said they were comfortable with Facebook. With regard to students' frequency of social media tool usage, students reported more frequent use of Facebook than with Twitter, blogging, or Wiggio. A majority of students said they used Facebook daily. Based on Facebook being reported by students as having the highest comfort level and highest frequency of use, Facebook could be a viable option for connecting and communicating with students.

Students reported both advantages and disadvantages in regards to the use of social media tools in the leadership classroom. Advantages included social media tools helping increase quality and efficiency of communication between students 
and the instructor, social media as a technological norm, access to class information, ease of collaboration, and stronger social connections between classmates. Students reported social media tools could be used effectively in the leadership classroom.

These findings confirm that the social context is critical to creating social presence when using online media (Tu \& McIsaac, 2002). Students emphasized the importance of connecting with each other and with instructors through social media for communication about class content, group activities and to cultivate social connections. These findings also confirm that interactivity is critical to creating social presence when using online media (Tu \& McIsaac, 2002). Leadership students in these classes noted that information exchange was quick and that they could communicate at all times of day about class projects.

Disadvantages were also reported by the students. Disadvantages included social media potentially becoming a distraction, issues related to the level of social media use by the students, the level of comfort with specific types of social media, loss of classroom interface, and problems with Internet access and consistency in the specific type of social media tool used in the classroom. Disadvantages revolved around issues of use of and access to social media.

The disadvantages students listed relate primarily to one piece of the social context construct in Tu and McIsaac's (2002) work with online media. Students must have a positive psychological attitude toward technology and toward the particular social media tool being used.

Some students stated that the use of such technology was an advantage because everyone was using social media; however, other students did not share the same outlook. They reflected that they wanted to maintain a distinction between personal and academic life, or that they were unfamiliar with the tools being used and feared losing out on opportunities to contribute to the class because of nonuse.

\section{Recommendations}

In this study students were more comfortable with and most frequently used Facebook as a social media outlet. In accordance with Wisniewski's (2010) findings that leadership students prefer digital learning outlets, students in this study perceived social media to be a technological norm. Instructors using social media in their classroom should encourage students to contact people in the class through Facebook, disseminate course information, and collaborate and connect socially using this social media tool.

Although many students in this study are comfortable with various social media tools, others indicated that they are not as comfortable using these outlets. Top (2012) found that computer knowledge was the strongest predictor of learning in a 
course using social media. Therefore, in accordance with Novak et al. (2012), it is recommended that in-class training in the use of social media outlets may be beneficial for the success of some students.

Many professors would already agree that social media is a constant distraction in the classroom. What used to be passing notes has become updating statuses and tweeting. It would be difficult for students to use social media in class and only focus on it as it relates to that particular course; this could be damaging the valuable classroom interface. Therefore, it is imperative for the instructor to create a sense of social presence as described by Tu and McIsaac (2002). Top (2012) also suggests that creating a sense of community in an online environment will aid in the success of social media as an educational tool.

In fulfilling students need for a sense of community, creating a comfortable social media environment instructors increase the probability that students will be successful in using social media as a formal learning tool (Tu \& McIsaac, 2002). As a part of the Social Presence Theory, attitude toward technology and access to technology are also issues that must be addressed. It is the recommendation of this study that social media components be made optional or even supplemental so that students who do not have regular access to the Internet or are not a part of a social media community may still be engaged in the course content. It is important to question whether or not it would be acceptable to force these students to become active in social media, preserving student choice as to whether they want to take part in this aspect of the class.

This freedom of choice in how students choose to acquire their information is in line with the andragogical models of Knowles et al. (2005) and Platz (1994). It allows students to gain a sense of ownership and control of their education. The online format also increases instructors' ability to guide the students from a lower level in the Staged Self-Directed Learning Model to become a level four selfdirected learner as described by Grow (1991) and by using strategies suggested by Brown (2012).

Future research should include a post-perception study after the use of social media in a leadership course to examine any change in perceived comfort level and frequency of use of social media tools. Future studies may also include the comparison of critical thinking and content retention between courses using social media tools and courses not using social media tools. Studies may also include how instructors may guide non-users of social media to attain higher levels within the Staged Self-Directed Learning Model (Grow, 1991).

This study was limited to students in two leadership courses at Texas A\&M University. A broader study would include more upper level leadership courses and courses across the university that integrates social media in their courses. 


\section{References}

Ary, D., Jacobs, L. C., \& Sorensen, C. K. (2010). Introduction to research in education $\left(8^{\text {th }}\right.$ ed.). Belmont, CA: Wadsworth Publishing Company.

Bass, B. M. (2008). The Bass handbook of leadership $\left(4^{\text {th }}\right.$ ed.). New York: Free Press.

Black, T. R. (2001). Understanding social science research $\left(2^{\text {nd }}\right.$ ed.). Thousand Oaks, CA: SAGE Publications.

Brown, S. A. (2012). Seeing Web 2.0 in context: A study of academic perceptions. Internet and Higher Education, 15, 50-57.

Chao, J. T., Parker, K. R., \& Fontana, A. (2011). Developing an interactive social media based learning environment. Issues in Informing Science and Information Technology, 8, 323-334.

Dabbagh, N., \& Kitsantas, A. (2012). Personal learning environments, social media, and self-regulated learning: A natural formula for connecting formal and informal learning. Internet and Higher Education, 15, 3-8.

DeAndrea, D. C., Ellison, N. B., LaRose, R., Steinfield, C., \& Fiore, A. (2012). Serious social media: On the use of social media for improving students' adjustment to college. Internet and Higher Education, 15, 15-23.

Fidishun, D. (2000). Andragogy and technology: Integrating adult learning theory as we teach with technology. Proceedings of the Mid-South Instructional Technology Conference, Murfreesboro, TN. Retrieved from http://www .eric.ed.gov/PDFS/ED446749.pdf

Franklin, T., \& Van Harmelen, M. (2007). Web 2.0 for content for learning and teaching in higher education, JISC. Retrieved from http://www.jisc.ac.uk /media/documents /programmes/digitalrepositories/web2-contentlearning-andteaching.pdf

Freishtat, R. L., \& Sandlin, J. A. (2010). Shaping youth discourse about technology: Technological colonization, manifest destiny, and the frontier myth in Facebook's public pedagogy. Educational Studies, 46, 503-523. doi: 10.1080/00131946.2010.510408

Garrison, D. R., Anderson, T., \& Archer, W. (2000). Critical inquiry in a textbased environment: Computer conferencing in higher education. The Internet and Higher Education, 2(2-3), 87-105. 
Gifford, G. T. (2010). A modern technology in the leadership classroom: Using blogs for critical thinking development. Journal of Leadership Education, 9(1), 165-172.

Glaser, B., \& Strauss, A. (1967). The discovery of grounded theory. Chicago, IL: Aldine.

Grow, G. O. (1991). Teaching learners to be self-directed. Adult Education Quarterly, 41(3), 125-149. doi: 10.1177/0001848191041003001

Gunawardena, C. N. (1995). Social presence theory and implications for interaction and collaborative learning in computer conferences. International Journal of Educational Telecommunications, 1(2/3), 147166.

Gunawardena, C. N., \& Zittle, F. J. (1997). Social presence as a predictor of satisfaction within a computer-mediated conferencing environment. The American Journal of Distance Education, 11(3), 8-26.

Guthrie, K. L. (2009). Situated technology as student tool for leadership instruction. Journal of Leadership Education, 8(1), 130-136. Retrieved from http://www.leadershipeducators.org/Resources/Documents/jole/2009 _summer/JOLE_8_1_Guthrie.pdf

Hughes, M., Ventura, S., \& Dando, M. (2007). Assessing social presence in online discussion groups: A replication study. Innovations in Education and Teaching International, 44(1), 17-29.

Johnson, D. M., Ferguson, J. A., \& Lester, M. A. (2000). Students enrolled in selected upper-division agriculture courses: an examination of computer experiences, self-efficacy and knowledge. Journal of Agricultural Education, 41(4), 62-72. doi: 10.5032/jae.2000 .04062

Johnson, D. M., Ferguson, J. A., \& Lester, M. (2002). Computer experiences, self-efficacy and knowledge of students entering a college of agriculture. North American Colleges and Teachers of Agriculture Journal, 46(1), 5867.

Johnson, D. M., \& Wardlow, G. W. (2004). Computer experiences, self-efficacy, and knowledge of undergraduate students entering a land-grant college of agriculture by year and gender. Journal of Agricultural Education, 45(3), 53-64. doi: 10.5032/jae.2004.03053

Knowles, M. S., Holton, E. F., \& Swanson, R. A. (2005). The adult learner $\left(6^{\text {th }}\right.$ ed.). Burlington, MA: Elsevier. 
Laru, J., Naykki, P., \& Jarvela, S. (2012). Supporting small-group learning using multiple Web 2.0 tools: A case study in the higher education context. Internet and Higher Education, 15, 29-38.

Marzano, R. J., \& Kendall, J. S. (2008). Designing and assessing educational objectives: Applying the new taxonomy. Thousand Oaks, CA: Corwin Press.

Morse, J. M. (2003). Principles of mixed methods and multimethod research design. In A. Tashakkori \& C. Teddlie (Eds.), Handbook of mixed methods in social and behavior research (pp. 189-208). Thousand Oaks, CA: Sage.

Novak, E., Razzouk, R., \& Johnson, T. E. (2012). The educational use of social annotation tools in higher education: A literature review. Internet and Higher Education, 15, 39-49.

Platz, D. L. (1994). Student directed planning: Fostering student ownership in learning. Education, 114(3), 420-422. Retrieved from http://content.ebscohostcom/pdf13_15/pdf/1994/EDU/01Mar94/94071106 11.pdf? $\mathrm{T}=\mathrm{PP}=\mathrm{AN} \& \mathrm{~K}=9407110611 \& \mathrm{~S}=\mathrm{R} \& \mathrm{D}=\mathrm{tfh} \& \mathrm{EbscoContent}=\mathrm{dGJy}$ MNLr40SeqLY4xNvgOLCmr0qeprZSsai4SrCWxWXS\&ContentCustome r=dGJyMPGus0m0q7JQuePfgeyx44Dt6fIA

Richardson, J. C., \& Swan, K. (2003). Examining social presence in online courses in relation to students' perceived learning and satisfaction. Journal of Asynchronous Learning Networks, 7(1), 68-88.

Roberts, G., \& Dyer, J. E. (2005). The influence of learning styles on student attitudes and achievement when an illustrated web lecture is used in an online learning environment. Journal of Agricultural Education, 46(2), 111. doi: $10.5032 /$ jae.2005.02001

Rourke, L., Anderson, T., Garrison, D. R., \& Archer, W. (2001). Assessing social presence in asynchronous text-based computer conferencing. Journal of Distance Education, 14. Retrieved from http://cade.athabascau.ca/vol14.2/rourke_et_al.html

Settle, Q., Telg, R., Irani, T., Rhoades, E., \& Rutherford, T. (2011). Instructors' social media use and preferences in agriculture classes. North American College and Teachers of Agriculture Journal, 54(3), 78-83.

Short, J., Williams, E., and Christie, B. (1976). The social psychology of telecommunications. John Wiley and Sons Ltd. 
Skurat-Harris, H. (2010). Digital students in the democratic classroom: Using technology to enhance critical pedagogy in first-year composition. Dissertation Abstracts International: Section A: Humanities and Social Sciences, 71(4A), 1288.

Strauss, A. L. (1987). Qualitative analysis for social scientists. Cambridge University Press.

Teddlie, C., \& Tashakkori, A. (2009). Foundations of mixed methods research: Integrating quantitative and qualitative approaches in the social and behavioral sciences. Thousand Oaks, CA: Sage.

Thomas, J. R., Davis, G. A., \& Moss, M. L. (2008). Efficacy of blended elearning tools: A case study. Journal of Applied Communications, 92(1 \& 2), 9-19.

Top, E. (2012). Blogging as a social medium in undergraduate courses: Sense of community best predictor of perceived learning. Internet and Society, 15, 24-28.

Tu, C. H., \& McIsaac, M. (2002). The relationship of social presence and interaction in online classes. American Journal of Distance Education, 16(3), 131-150. doi: 10.1207/S15389 286AJDE1603_2

Van Manen, M. (2010). The pedagogy of Momus technologies: Facebook, privacy, and online intimacy. Qualitative Health Research, 20(8), 10231032. doi: $10.1177 / 1049732310364990$

Williams, J., \& McClure, M. (2010). The effects of teaching methods in leadership knowledge retention: An experimental design of lecture, experiential, and public pedagogy. Journal of Leadership Education, 9(2), 86-100. Retrieved from http://www.leadershipeducators.org/Resources /Documents/jole/2010_summer/Williams_and_McClure.pdf

Wisniewksi, M. A. (2010). Leadership and the Millennials: Transforming today's technological teens into tomorrow's leaders. Journal of Leadership Education, 9(1), 53-67.

Wodzicki, K., Schwammlien, E., \& Moskaliuk, J. (2012). “Actually, I wanted to learn": Study-related knowledge exchange on social networking sites. Internet and Higher Education, 15, 9-14.

Yan, A. Y., Tian, S. W., Vogel, D., \& Kwok, R. C. (2010). Can learning be virtually boosted? An investigation of online social networking. Computers \& Education, 55, 1494-1503. 


\section{Author Biographies}

Summer F. Odom, Ph.D., is an Assistant Professor in the Department of Agricultural Leadership, Education, \& Communications (ALEC) at Texas A\&M University. She teaches courses in personal and professional leadership. Dr. Odom received her doctorate in Human Resource Development in May 2011. Her research interests include leadership and life skill capacity building of young adults with a focus on collegiate leadership education, delivery strategies in teaching leadership to diverse populations, and core beliefs and values in the field of leadership education.

M'Randa Sandlin is a doctoral candidate in The Department of Agricultural Leadership, Education and Communications at Texas A\&M University. She received her M.S. from Texas A\&M University in 2010 and B.S. from Texas Tech University in 2005. Her research interests include leadership development, adoption diffusion theory, and student and faculty development through innovative delivery methods.

Holly D. Jarvis, Ph.D., is the Coordinator of Educational Media and Online Curriculum Development for Texas A\&M AgriLife Extension. She manages publication of educational materials including publications, videos and online courses. Dr. Jarvis received her doctorate in Agricultural Leadership, Education and Communications from Texas A\&M University in May 2012. Her professional interests include production of learner-centered educational materials, providing professional development for extension specialists, and developing continuing education curricula.

Cassidy Peek is pursuing her master's degree in Agricultural Leadership, Education, \& Communications from Texas A\&M University and works as a graduate assistant. She received her B.S. degree from Texas A\&M University in Agricultural Leadership \& Development in 2011. 